\title{
The Effect of Authentic and Inauthentic Materials in Cultural Awareness Training on EFL Learners' Listening Comprehension Ability
}

\author{
Behzad Barekat \\ English Department, University of Guilan, Rasht, Iran \\ Hamed Nobakhti \\ English Department, University of Guilan, Rasht, Iran
}

\begin{abstract}
This paper aimed to examine the effect of authentic and inauthentic materials in cultural awareness training on the listening comprehension ability of EFL learners. To this end, the Cambridge ELT placement test was given to 116 students, 60 of them who were at intermediate level were chosen as the sample. The participants were randomly divided into two equal groups, the control and experimental groups. They also took a listening pretest to investigate the possible difference between them. The control group underwent listening activities through inauthentic materials, while the experimental group dealt with authentic materials. Test scores in pre- and post-test were compared. Using SPSS, the Kolmogorov-Smirnov test of normality was run for the post-test scores to check the applicability of parametric statistics. A Paired-Sample T-Test proved that the listening comprehension ability of the participants has improved in a statistically significant way. A One-way ANOVA test was then run to compare the mean-scores of the groups in the post-test. All tests were at the alpha level of .05 . The results revealed that the listening ability of learners in the experimental group had improved better than the learners in the control group. This study may have implications for improving EFL learners' listening ability.
\end{abstract}

Index Terms - authentic materials, inauthentic materials, listening comprehension ability

\section{INTRODUCTION}

Listening is an important skill through which language learners internalize linguistic information without which they cannot produce language (Brown, 2007). According to Rubin \& Thompson (1994), among the four language skills_ listening, speaking, reading, and writing _ listening is possibly the most conspicuous and elemental one, because language users spend nearly $60 \%$ of their time listening. As Flowerdew (1994) claims, in daily life listening is used the most frequently (42\%), pursued by speaking (32\%), reading (15\%), and writing (11\%).

Chastain remarks that listening functions as "the basis for development of speaking" (1976, cited in Chen 2003). Hence listening proves to be the natural prerequisite in learning a second or foreign language, just like first language acquisition. Listening necessitates cognitive processes, physiological processes, and attention to contextual and "socially coded acoustic clues" (Swaffar \& Bacon, 1993; Field, 2002; Lynch, 2002; Rost, 2002).

In spite of all these, listening was once supposed to be a passive skill, enjoying little research and classroom attention. But today listening is identified as an active process, crucial to foreign and second language acquisition and worthy of methodical evolvement as a skill in its own regard (Morley, 1999). In recent years, substantial effort has been dedicate to formulating theories elucidating decisive factors that could enhance foreign language listening comprehension (Nagle \& Sanders, 1986; Buck, 1991). Although still there exists no generally accepted theory on foreign language listening comprehension development, some researchers (e.g. Richards, 1983; Christine \& Christa, 1995) think that listeners' linguistic knowledge and background knowledge are the necessary factors that are capable of influencing their comprehension of the foreign language.

Thus understanding the chemistry of listening processes proves to be of utmost significance, since it performs a principal role in second or foreign language acquisition. Numerous researchers have scrutinized the difficulties that language learners encounter while listening. O'Malley, Chamot, and Kupper (1989) have mentioned Inattention as one of these difficulties learners suffer. Goh (1997) claims if learners are not familiar with the strategies used, they will probably have problems while listening. Lexis, is one other difficulty that impedes learners' progress (Kelly, 1991). Chen (2002) mentions fast rate of speech as one other difficulty for progressive understanding. But, maybe the most influential element that could prove itself as a major difficulty for learners' listening comprehension is Background knowledge (Long, 1990; Chiang \& Dunkel, 1992).

Among these factors learners' background knowledge and content schemata can affect the quality of listening comprehension to a large extent. Research in reading corroborates the idea that activating background knowledge and applying this knowledge to new input greatly expedite the processing and understanding of texts (Graves \& Cook, 
1980). Listening's major purpose is the construction of meaning by matching what listeners hear with what they already know, i.e. their background knowledge (Rost, 2002). One aspect of background knowledge is culture that is embedded in even the simplest act of language (Hao, 2000; Kramsch, 1993). Kramsch (1993) maintains that every time we speak we perform a cultural act. Accordingly, cultural knowledge as a basis for language learning is now emphasized in modern language teaching.

This knowledge_ background knowledge, and/or cultural knowledge_ presents itself in the facilitation of the input processing inferentially, i.e. the language user makes inferences in the process of decoding the message. These inferences should necessarily conform to the semantic, pragmatic, and particularly discursive codes of any specific language, here the target language. Thus background knowledge, or more specifically cultural knowledge, is necessary for the language user to be able to make appropriate inferences. As Rost (1990, p. 9) claims, the notion of listening is often considered in parallel to reading; both are texts with which readers interact, although the information in written or spoken text is packaged differently. Indeed, Eysenk (1990, p. 224), Clark and Clark (1977, p. 97) and Rost (1990, p. 62), do in fact indicate that listeners must utilize inferencing skills in order to make sense of discourse.

In an EFL classroom there are limited sources for students to learn the culture of the target language. Among these sources authentic materials such as movies and series could be more effective since they present the target culture unabridged. As Herron, Cole, Corrie, and Dubreil (1999) showed, students achieve significant gains in overall cultural knowledge after watching videos from the target culture in the classroom.

Due to their very nature, authentic materials_ unchanged texts that are produced by and for native speakers (Bacon, 1992) _ more effectively promote the learning of procedural and experiential knowledge, while inauthentic materials promote the learning of conceptual knowledge more effectively (Ellis, 2008).

Thus the objective set for this study is: To find out whether or not authentic materials are more effective than inauthentic materials in improving the listening comprehension ability of EFL learners at the intermediate level. This research thus addresses the following question:

Q. Are authentic materials more effective than inauthentic materials in improving the listening comprehen sion ability of EFL learners at the intermediate level?

$\mathrm{H}_{0}$. Authentic materials are not more effective than inauthentic materials in improving the listening comprehension ability of EFL learners at the intermediate level.

\section{THEORETICAL AND RESEARCH BACKGROUND}

\section{A. Cognitive Models of Listening Process: The Bottom-up, Top-down, and Interactive Processing Models}

In bottom-up processing, the various elements of the discourse, from the phonemes to the sentences, are analyzed. This analysis requires the comprehensive linguistic features processing of a given language. In this type of processing the language user attempts to correspond the initial sounds of new words to their own lexicon to guess what a word probably is. This matching might happen before all sounds have been heard because of the elimination process. According to Field (1999), this process might last no more than 0.25 second, and the processes of analyzing and processing of phonemes, syllables, words, phrases, and sentences probably occur at the same time. If learners face input for which they do not have any background knowledge, they might rely on bottom-up processing (Wilson, 2003).

The term top-down processing is used in description of the cognitive processes of listening and reading. In this type of processing, the learner relies on background knowledge to infer what the intentions of the speaker could be. According to Jung (2003), language users adopt factual knowledge of here and now and consider different types of schemata that help them foretell what will come next through top-down processing. According to Rost (2005) two types of schemata exist: content and formal schemata, content schemata deal with the factual discourse content, the message which is intended, while formal schemata deals with the organization of discourse.

According to Park (2004), the Interactive Process model reveals how both top-down and bottom-up processing types mingle for comprehension to take place. Bottom-up demands linguistic knowledge and top-down occurs by activating the background knowledge. Comprehension best takes place through the interaction of both.

\section{B. Culture: Definition, Themes, and Sources of Culture}

According to Hinkel (1999), culture refers to areas of inquiry into human societies, groups, systems, behaviors, and activities. According to Moran (2001), culture is "the great achievement of people as reflected in their history, social institutions, works of art, architecture, music, and literature" (p. 4).

Adaskou, Britten, and Fahsi (1990) define culture by outlining four meanings of it: aesthetic sense, sociological sense, semantic sense, and pragmatic or sociolinguistic sense. The last one covers background knowledge, language code, and social skills which are essential for successful communication.

According to these definitions language is an aspect of culture because language is basically learned and shared by man as a member of society. As Mitchell and Myles (2004) postulate, culture and language are the same in nature, acquired together and providing support for the enhancement of each other. Liddicoat et al. (2003) claim that no level of language is independent of culture. According to Kramsch (1998B the point that language expresses and symbolizes culture proves that language and culture are tightly bounded to each other. 'A fluent fool' is what Bennett, Bennett \& Allen, (2003, p. 237) call the person who learns a language without learning its culture. Richards and Rodgers (2001) 
argue that for humans, language is the most important means of communication (as cited in Liu \& Laohawiriyanon, 2013).

According to Lee (2009) and Peterson (2004) two types of culture can be assumed: the Big "C" and the Little " $c$ ". Lee (2009, as cited in Liu \& Laohawiriyanon, 2013) sees Big " $C$ ” culture as the culture which shows a series of facts and statistics relating to the history, arts, festivals, education, business, geography and customs of a target speech society. For Peterson (2004, as cited in Liu \& Laohawiriyanon, 2013) the culture relating to grand themes, is classified under Big " $C$ " culture which includes the following themes such as geography, architecture, classical music, literature, political issues, society's norms, legal foundation, core values, history, and cognitive processes. For Lee (2009, p. 78, as cited in Liu \& Laohawiriyanon, 2013) this type of culture is "the invisible and deeper sense of a target culture" including attitudes or beliefs and assumptions. Peterson (2004, as cited in Liu \& Laohawiriyanon, 2013) defines Little "c" culture as the culture focusing on common or minor themes. It includes themes such as opinions, viewpoints, preferences or tastes, gestures, body posture, use of space, clothing styles, food, hobbies, popular music, and popular issues, and certain knowledge (trivia) facts. However, it can also possibly result in "pragmatic failure" when attempting to communicate with other cultural groups. Therefore, if EFL learners know about small "c" culture in the target culture, they will better comprehend how those people communicate with each other in that culture (Lee, 2009, as cited in Liu \& Laohawiriyanon, 2013).

Sources of cultural information could be classified into: source culture (learner's own culture), target culture (any English-speaking countries where English is spoken as a first language), and international target culture (English speaking or non-English speaking countries around the world, where English is not used as a first language) (Cortazzi and Jin, 1999, as cited in Liu \& Laohawiriyanon, 2013).

\section{Materials Used for Teaching Culture: Authentic and Inauthentic}

What type of culture should be taught in the SL/FL classroom? Relating the essential ideas provided by the previously mentioned definitions and the reasons for the inevitability of incorporating cultural matters into the SL/FL classroom, it is apparent that the major forms of culture we need to deal with in a foreign language program should be the one that views culture as a "blue print" or integrated patterns of abstraction derived from observable behavior of a group of people. In other words, the major cultural contents to include in a language classroom should be what Tomalin and Stempleski (1993) call with the little "c" of culture. In relation to this, Brooks (1983) suggests that the cultural elements to be emphasized in the classroom are models of living. Therefore, realistic elements of culture we should include are notions like when and what people eat, how they earn money, the ideas they have toward their friends and families, how they show approval or disapproval of something, educational attitudes, time and space patterns, work values, and etc. In this sense, culture is a set of solutions to the problems. Although the concrete forms of culture like painting, music, tools, and facts of history or geography are interesting to discuss, since they do not provide an intimate view of what life is really like in the target culture, they are not of high important to deal with in relation to the teaching of a foreign language.

The term 'authentic materials' means different things to different people in the literature. The common theme in the definitions given for 'authentic materials' is 'real language and its use in its own community'. The most common definition for second-language research is 'unaltered texts that are produced by and for native speakers' (Bacon, 1992; Joiner et al., 1989). Jordan (1997, p. 113) refers to authentic texts as "texts that are not written for language teaching purposes".

Guariento and Morley (2001) claim that at post-intermediate levels, the use of authentic materials is advantageous. It is probably because at these levels most students know a wide range of vocabulary and all of the structures. Accordingly, they claim that at lower levels the use of authentic materials may discourage and frustrate students since they lack enough lexical items and structures necessary for dealing with authentic materials.

Authentic materials are culturally rich and thus more interesting (Bacon, 1992). Authentic materials can give students direct access to the cultural information need and help them use the target language authentically (Rogers \& Medley, 1988). Stagich (1998) claims that understanding cultural context is the most effective way to learn real meaning of the language.

According to Rivers (1981), movies and series, as authentic materials, could be used as the medium of study of the culture for the development of cultural awareness. Movies and Series offer students a chance to see behaviors that are not seen in texts. Movies and Series involve students with issues of language and culture simultaneously (Stephens, 2001). The study by Herron, Cole, Corrie, and Dubreil (1999) showed that learners' cultural knowledge significantly improved after watching videos from the target culture.

\section{Consciousness Raising Tasks}

Consciousness raising tasks for cultural awareness training were carried out in both groups. The tasks were devised in line with the characteristics of Consciousness Raising given by Ellis (2003). The purpose was to make subjects in these groups aware of the possible differences between the Iranian and American cultures. Considering the requirements of this study, these features were revised by the researcher in the following way:

1. The "attempt to isolate a specific linguistic feature for focused attention". Revised version: Isolating a specific cultural feature for focused attention. 
2. The provision of "data which illustrate the targeted feature". Revised version: Providing learners with relevant data for illustrating the target culture features.

3. The requirement that learners 'utilize intellectual effort' to understand the targeted feature. Revised version: Requiring learners to utilize intellectual effort to understand the targeted cultural feature.

\section{MethodOLOGY}

\section{A. Participants}

Initially a placement test was administered among the 116 candidates who had registered to participate in this study in the English department of Novinpouyan Cultural Institute in Arak, Iran. Among those who qualified as intermediate, 60 were randomly chosen to be randomly assigned to the experimental and control groups. Among these 60 participant, 30 were males and 30 were females. The age of the participants ranged from 19 to 28. Their first language was Persian and 6 of them had travelled to non-English speaking countries as tourists.

Intermediate level participants were chosen because the description of what a learner is supposed to be able to do in reading, listening, speaking and writing at the intermediate level, provided by CEFR (Martyniuk, 2005), best fulfilled the theoretical assumptions of the study which are thoroughly discussed in the second chapter.

\section{B. Materials: Authentic Materials, Inauthentic Materials}

Three types of material were used in this study: authentic materials, inauthentic materials, which are both in American accent, and consciousness raising tasks. According to Rivers (1981), movies and series could be used as the medium of study of the culture for the development of cultural awareness. The study conducted by Herron, Cole, Corrie, and Dubreil (1999) showed that students achieved significant gains in overall cultural knowledge after watching authentic videos from the target culture. Based on what has been previously done in studying the efficacy of authentic videos in cultural training of students, an American television comedy-drama, Shameless, on SHO January 9, 2011 present, was selected to be used in the experimental group.

The listening activities to be used in the control group were chosen from the following course books: American English File by Clive Oxenden et al., Impact Values by Richard Day, et al., Tactics for Listening by Jack C. Richards, Tune in by Jack C. Richards and Kerry O’Sullivan, Listen In by David Nunan.

\section{Instruments: Placement and Listening Tests}

Cambridge (Oxford) ELT placement test was administered among 116 candidates to select the sample of this study. The test used to investigate the possible difference between control and experiment groups was a standard TOEFL listening test.

\section{Procedures}

To select the subjects necessary for this study the Cambridge (Oxford) ELT placement test was administered. The candidates were asked to start at the beginning of the written test and stop when the questions become too difficult. The maximum time allowed for this section of the test was 40 minutes. 116 candidates took this test. Due to space limitations, it was impossible to administer this test at one session, thus it took four sessions to administer this test.

The oral section of the placement test was administered by two raters among the students with scores within the preintermediate ( 9 students), intermediate (56 students), and upper intermediate (41 students) categories. The oral test took six sessions to be administered. After administering the oral test 72 students proved to be at the intermediate level.

Since in this study 60 participants were needed, the researchers had to randomly cross out 12 candidates, leaving 60 participants to be divided into control and experimental groups.

To check the participants' listening ability level prior to the treatment, the TOEFL listening pretest was administered among them.

Then each group received instruction using the predetermined type of listening material during the course of twelve weeks. The classes were held three times a week. After receiving 36 sessions of treatment the post-test was administered.

\section{RESUlts}

\section{A. Placement Test Scores Analysis}

The following table shows the results of the placement test:

TABLE 1

\begin{tabular}{llllll}
\multicolumn{5}{c}{ TABLE 1 } \\
& \multicolumn{5}{c}{ PlaceMENT TEST RESUlts } \\
\hline scores & 116 & 29.00 & 113.00 & 74.2500 & 15.10075 \\
\hline
\end{tabular}

As it is clearly shown in the above table, the mean score and standard deviation are approximately 74 and 15 respectively. 106 candidates were allowed to take the proceeding oral section of the placement test after being 
provisionally placed in the pre-intermediate, intermediate, and upper intermediate categories provided by the Cambridge (Oxford) ELT placement test guide.

An inter-rater reliability analysis using the Kappa statistic was performed to determine consistency among raters. The data on the assignment of categories by the two raters is presented in the following chart:

TABLE 2

\begin{tabular}{|c|c|c|c|c|c|}
\hline & & \multicolumn{4}{|c|}{ RATERS A*B CROSSTABULATION } \\
\hline & & \multicolumn{3}{|c|}{$\mathrm{B}$} & \multirow[t]{2}{*}{ Total } \\
\hline & & Pre-intermediate & Intermediate & Upper-intermediate & \\
\hline \multirow[t]{3}{*}{ A } & Pre-intermediate & 6 & 3 & 0 & 9 \\
\hline & Intermediate & 3 & 80 & 3 & 86 \\
\hline & Upper-intermediate & 0 & 4 & 7 & 11 \\
\hline Total & & 9 & 87 & 10 & 106 \\
\hline
\end{tabular}

The results of the Kappa statistical measure are shown in the following chart:

TABLE 3

SYMMETRIC MEASURES

Value Asymp. Std. Error Approx. T Approx. Sig.

The interrater reliability for the raters was found to be 0.613 , according to Landis and Koch (1977) if the values of Kappa are from 0.61 to 0.80 , there is substantial agreement between the raters.

B. Descriptive Results of the Pretest Scores

TABLE 4

DESCRIPTIVE STATISTICAL RESULTS OF THE PRETEST SCORES

\begin{tabular}{llllllll}
\hline & $\mathrm{N}$ & Minimum & Maximum & Mean & & Std. Deviation & Variance \\
& Statistic & Statistic & Statistic & Statistic & Std. Error & Statistic & Statistic \\
\cline { 2 - 7 } & 30 & 14.00 & 27.00 & 19.8667 & .60787 & 3.32942 & 11.085 \\
Pretest Control & 30 & 14.00 & 28.00 & 20.6333 & .66347 & 3.63397 & 13.206 \\
Pretest Experimental & 30 & & & & & & \\
Valid N (listwise) & 30 & & & & & \\
\hline
\end{tabular}

According to table 4, the mean score of the control group in the pretest is 19.86 and the minimum and maximum scores are 14 and 27, respectively. The mean score of the experiment group is 20.63 and the range of scores is from 14 to 28 .

To confirm the homogeneity of the control and experimental groups, the pretest scores were analyzed through the one-way ANOVA test. The results are shown in the following chart.

TABLE 5

TEST OF BETWEEN-SUBJECT EFFECTS: PRETEST SCORES

\begin{tabular}{llllll}
\hline \multicolumn{5}{l}{ TEST OF BETWEEN-SUBJECT EFFECTS: PRETEST SCORES } \\
& $\begin{array}{l}\text { Type III Sum of } \\
\text { Squares }\end{array}$ & df & Mean Square & F & Sig. \\
\hline Corrected Model & $8.817^{\text {a }}$ & 1 & 8.817 & .726 & .398 \\
Intercept & 24603.750 & 1 & 24603.750 & 2025.767 & .000 \\
group & 8.817 & 1 & 8.817 & .726 & .398 \\
Error & 704.433 & 58 & 12.145 & & \\
Total & 25317.000 & 60 & & & \\
Corrected Total & 713.250 & 59 & & & \\
\hline
\end{tabular}

Since the p-value in the above table is 0. 398, the two groups are homogeneous.

\section{Descriptive Results of the Post-test Scores}

The descriptive statistical results of the listening comprehension post-test scores of all groups are reported in table 6.

TABLE 6

DESCRIPTIVE STATISTICAL RESULTS OF THE POST-TEST SCORES

\begin{tabular}{|c|c|c|c|c|c|c|c|}
\hline & $\begin{array}{l}\mathrm{N} \\
\text { Statistic }\end{array}$ & $\begin{array}{l}\text { Minimum } \\
\text { Statistic }\end{array}$ & $\begin{array}{l}\text { Maximum } \\
\text { Statistic }\end{array}$ & $\begin{array}{l}\text { Mean } \\
\text { Statistic }\end{array}$ & Std. Error & $\begin{array}{l}\text { Std. Deviation } \\
\text { Statistic }\end{array}$ & $\begin{array}{l}\text { Variance } \\
\text { Statistic }\end{array}$ \\
\hline Post-test Control & 30 & 16.00 & 30.00 & 21.9667 & .70055 & 3.83705 & 14.723 \\
\hline Post-test Experimental & 30 & 19.00 & 33.00 & 25.7667 & .74229 & 4.06570 & 16.530 \\
\hline Valid N (listwise) & 30 & & & & & & \\
\hline
\end{tabular}

According to table 6, the mean score of the control group in the post-test is 21.96 and the minimum and maximum scores are 16 and 30, respectively. The mean score of the experiment group is 25.76 and the range of scores is from 19 to 33 .

To check the normality of the post-test scores the Kolmogorov-Smirnov test of normality was also run. This was to confirm that parametric statistics could legitimately be used for this study. Table 7 shows the result of this test. 
TABLE 7

ONE-SAMPLE KOLMOGOROV-SMIRNOV TEST

\begin{tabular}{ll}
\hline & Post-test scores \\
\hline Kolmogorov-Smirnov Z & .896 \\
Asymp. Sig. (2-tailed) & .399 \\
\hline
\end{tabular}

According to the above table, Kolmogorov-Smirnov $\mathrm{Z}$ equals .896 and the p-value is .399, thus the data comes from a normal distribution and using parametric statistics in this study is legitimate.

\section{The Statistical Analysis of the Post-test Scores: The Effect of Material Types}

To examine the effect of material types on the listening comprehension ability of the participants, two steps were taken. The first step was to check if the treatment has been effective in improving the listening comprehension ability of the participants from a statistically significant point of view. To this end a Paired-Sample T-Test was run. The results of this test are shown in the following table.

TABLE 8

PAIRED SAMPLE TEST

\begin{tabular}{|c|c|c|c|c|c|c|c|c|}
\hline \multicolumn{9}{|c|}{ (2) } \\
\hline & \multicolumn{5}{|c|}{$\underline{\text { Paired Differences }}$} & \multirow[t]{3}{*}{$\mathrm{t}$} & \multirow[t]{3}{*}{ df } & \multirow[t]{3}{*}{ Sig. (2-tailed) } \\
\hline & \multirow[t]{2}{*}{ Mean } & \multirow[t]{2}{*}{ Std. Deviation } & \multirow[t]{2}{*}{$\begin{array}{l}\text { Std. Error } \\
\text { Mean }\end{array}$} & \multicolumn{2}{|c|}{$\begin{array}{l}95 \% \text { Confidence Interval of the } \\
\text { Difference }\end{array}$} & & & \\
\hline & & & & Lower & Upper & & & \\
\hline Pre control - Post control & -2.10000 & 3.99439 & .72927 & -3.59153 & -.60847 & -2.880 & 29 & .007 \\
\hline Pre Experi - Post Experi & -5.13333 & 3.41127 & .62281 & -6.40712 & -3.85954 & -8.242 & 29 & .000 \\
\hline
\end{tabular}

According to table 8 , since all p-values are less than .05 it is confirmed that the treatment has significantly improved the listening comprehension ability of the participants.

In the second step the mean-scores in the post-test were compared running a one-way ANOVA test. The result of this test is presented in table 9 .

TABLE 9

TESTS OF BETWEEN-SUBJECTS EFFECTS

\begin{tabular}{llllll}
\hline & Type III Sum of Squares & df & Mean Square & F & Sig. \\
\hline Group & 216.600 & 1 & 216.600 & 13.861 & .000 \\
\hline
\end{tabular}

According to table 9 , the p-value is .000 , this shows the mean-score of the experimental group is significantly different from the mean-score of the control group. Since the mean-score of the experimental group is 25.7667 and the mean-score of the control group is 21.9667, it is proved that the experimental group has outperformed the control group.

Thus, it is concluded that the null hypothesis is rejected and authentic materials are more effective than inauthentic materials in improving the listening comprehension ability of EFL learners at the intermediate level.

\section{DisCUSSION AND CONCLUSION}

This study aimed at investigating the effect of authentic and inauthentic materials in cultural awareness training on EFL learners listening comprehension ability. To this purpose two groups of intermediate EFL students took part in a series of listening comprehension classes. One group (Control) was taught using inauthentic material, whereas the other group (Experimental) received instruction using authentic materials.

Regarding the research question that is "Are authentic materials more effective than inauthentic materials in improving the listening comprehension ability of EFL learners at the intermediate level?" it can be concluded from the results that authentic materials could be more effective than inauthentic materials in improving the listening comprehension ability of EFL learners at the intermediate level.

Further research is needed to investigate the effect of other authentic materials on the listening comprehension ability of EFL learners at the intermediate level. Finally, it must be pointed out that further research is needed to be done considering other proficiency levels.

\section{REFERENCES}

[1] Adaskou, K., Britten, D., \& Fahsi, B. (1990). Design decisions on the cultural content of a secondary English course for morocco. ELT Journal, 44(1), 3-10.

[2] Alptekin, C. (1993). Target-language culture in ELT materials. ELT Journal, 47(2), 136-143.

[3] Bacon, S. M. (1992). Phases of listening to authentic input in Spanish: A descriptive study. Foreign Language Annals, 25, $317-$ 334.

[4] Bennett, J., Bennett, M., \& Allen, W. (2003). Developing intercultural competence in the language classroom. In culture as the core: Perspectives in second language learning. USA: Information Age Publishing.

[5] Brooks, N. (1983). Teaching culture in the foreign language classroom. Foreign Language Annals, 16. New York: ACTEFL, Inc.

[6] Brown, H. D. (2007). Principles of language learning and teaching (5th ed.). White Plains, NY: Longman.

[7] Buck. (1991). The testing of listening comprehension: an introspective study. Language Testing, 8(1), 67-91. 
[8] Chastain, K. (1976). Developing Second Language Skills: Theory to Practice (2 ${ }^{\text {nd }}$ ed.). Chicago: Rand McNally College Publishing Company.

[9] Chen, M.F. (2003). The role of motivation on EFL students' listening comprehension in Taiwan. Master's thesis, National Kaohsiung Normal University, Kaohsiung, Taiwan.

[10] Chen, S.W. (2002). Problems in listening comprehension for learners of EFL. Studies in English Language and Literature, 10, 57-70.

[11] Chiang, Ch. S., \& Dunkel, P. (1992). The effect of speech modification, prior knowledge, and listening proficiency on EFL lecture learning. TESOL Quarterly, 26, 345-374.

[12] Christine, J., \& Christa, H. (1995). The effect of prior knowledge on EAP listening-test performance. Language Testing, 12(1), 99-119.

[13] Clark, H. H., \& Clark, E. V. (1977). Psychology and Language: An Introduction to Psycholinguistics. New York: Harcourt Brace Javanovich.

[14] Cortazzi, M., \& Jin, L. X. (1999). Cultural mirrors: materials and method in the EFL classroom. In Hinkel, E. (ed.), Culture in Second Language Teaching (pp. 196-219). Cambridge: Cambridge University Press.

[15] Phillips, D. (2003). Longman Preparation Course For The TOEFL ${ }^{\circledR}$ Test: The Paper Test: NY: Longman.

[16] Ellis, R. (2003). Task-based Language Learning and teaching. Oxford: Oxford University Press.

[17] Ellis, R. (2008). The study of second language acquisition ( $2^{\text {nd }}$ ed.). Oxford: Oxford University Press.

[18] Eysenck, M. (1990). The Blackwell Dictionary of Cognitive Psychology. London: Blackwell.

[19] Field, J. (1999). Key concepts in ELT: "bottom-up" and "top-down". ELT Journal, 9, 29-34.

[20] Field, J. (2002). The changing face of listening. In J. Richards \& W. Renandya (Eds.), Methodology in language teaching: An anthology of current practice (pp. 242-247). Cambridge: Cambridge University Press.

[21] Flowerdew, J. (1994). Academic listening: Research perspectives. Cambridge: Cambridge University Press.

[22] Goh, C., (1997). Metacognitive awareness and second language listeners. ELT Journal, 51, 361-369.

[23] Graves, M., \& Cook, C. (1980). Effects of previewing difficult short stories for high school students. Research on Reading in Secondary Schools, 6, 38-54.

[24] Guariento, W. \& Morley, J. (2001). Text and task authenticity in the EFL classroom. ELT Journal 55(4), 347-353.

[25] Hao, T. (2000). On factors of influencing English listening teaching and learning. Retrieved July, 2013, from http://zhushenhai.anyp.cn.

[26] Herron, C., Cole, S. P., Corrie, C., \& Dubreil, S. (1999). The effectiveness of video-based curriculum in teaching culture. The Modern Language Journal, 83(4), 518-533.

[27] Hinkel, E. (1999). Culture in second language teaching and learning. Cambridge: Cambridge University Press.

[28] Joiner, E. G., Adkins, P. B., \& Eykyn, L. B. (1989). Skimming and scanning with Champs-Elysees: Using authentic materials to improve foreign language listening. The French Review, 62, 427-435.

[29] Jordan, R. R (1997). English for Academic Purposes: A Guide and Resource for Teachers. Cambridge. Cambridge University Press.

[30] Jung, E. H. (2003). The role of discourse signaling cues in second language listening comprehension. The Modern Language Journal, 87, 562-577.

[31] Kelly, P., (1991). Lexical ignorance: The main obstacle to listening comprehension with advanced FL learners. IRAL, 29, 135150.

[32] Kramsch, C. (1993). Teaching culture in literature in the ESL/EFL classroom. Retrieved July, 2013, from http://iteslj.org/Lessons/Plastina-CultureInLiterature.

[33] Kramsch, C. (1998). Language and culture. Oxford: Oxford University Press.

[34] Landis, J. R., Koch, G. G. (1977). The measurement of observer agreement for categorical data. Biometrics, 33, $159-174$.

[35] Lee, K. Y. (2009). Treating culture: what 11 high school EFL conversation textbooks in South Korea. English Teaching: practice and Critique, 8, 76-96.

[36] Liddicoat, A.J., Papademetre, L., Scarino, A., \& Kohler, M. (2003). Report on intercultural language learning. Canberra ACT: Commonwealth of Australia.

[37] Liu, S., Laohawiriyanon, C. (2013). Cultural Content in EFL Listening and Speaking Textbooks for Chinese University Students, International Journal of English Language Education 1(1), 82-93

[38] Lynch, T. (2002). Listening: Questions of level. In R. B. Kaplan, (Ed.), Oxford handbook of applied linguistics (pp. 39-48). Oxford: Oxford University Press.

[39] Martyniuk, W. (2005). Common European Framework of Reference for Languages: Learning, teaching, assessment (CEFR)-a synopsis. Retrieved June 3, 2013, from http://server.lrc.cornell.edu/events/past/2005-2006/martyniuk.doc.

[40] Mitchell, R., \& Myles, F. (2004). Second language learning theories (2nd ed.). London: Arnold.

[41] Moran, P. R. (2001). Teaching culture: Perspectives in practice. Boston: Heinle \& Heinle.

[42] Morley, J. (1999). Current perspectives on improving aural comprehension. Retrieved June, 2013, from http://www.eslmag.com/MorleyAuralStory.htm.

[43] Nagle, S. J., \& Sanders, S. L. (1986). Comprehension theory and second language pedagogy. TESOL Quarterly, 20(1), 9-26.

[44] O’Malley, J. M., Chamot, A. U., \& Kupper, L. (1989). Listening comprehension strategies in second language acquisition. Applied Linguistics, 10, 418-437.

[45] Park, G.E. (2004). Comparison of L2 listening and reading comprehension by university students learning English in Oxford, R. L. (1999). Learning strategies. In B. Spolsky, Concise encyclopedia of educational linguistics (pp. 518-522). Oxford: Elsevier.

[46] Peterson, B. (2004). Cultural intelligence: A guide to working with people from other cultures. Yarmouth, ME: Intercultural Press.

[47] Richards, J. C. (1983). Listening comprehension: Approach, design, procedure. TESOL Quarterly, 17(2), 219-240.

[48] Richards, J., \& Rodgers, T. (2001). Approaches and methods in language teaching ( $2^{\text {nd }}$ ed.). Cambridge: Cambridge University Press. 
[49] Rivers, W. M. (1981). Teaching foreign language skills (2nd ed.). Chicago: University of Chicago Press.

[50] Rogers, C. V., \& Medley, F. W., Jr. (1988). Language with a purpose: Using authentic materials in the foreign language classroom. Foreign Language Annals, 21, 467-478.

[51] Rost, M. (1990). Listening in language learning. New York: Longman.

[52] Rost, M. (2002). Teaching and researching listening. London, UK: Longman.

[53] Rost, M. (2005). L2 listening. In E. Hinkel, Handbook of research on second language learning and teaching (pp. 503-527). Mahwah, NJ: Erlbaum.

[54] Rubin, J. \& Thompson, I. (1994). How to be a more successful language learner: Toward learning autonomy. MA: Heinle \& Heinle Publishers.

[55] Stagich, T. (1998). Cultural context and meaning in foreign language learning. General Linguistics, 36, 71-79.

[56] Stephens, J. L. (2001). Teaching culture and improving language skills through a cinematic lens: A course on Spanish film in the undergraduate Spanish curriculum. ADFL Bulletin, 33(1), 22-25.

[57] Swaffar, J. K., \& Bacon, S. M. (1993). Reading and listening comprehension: Perspectives on research and implications for practice. In A. H. Omaggio (Ed.), Research in language learning: Principles, processes, and prospects (pp.124-155). Lincolnwood, IL: National Textbook.

[58] Tomalin, B., \& Stempelski, S. (1993). Cultural awareness. Oxford: Oxford University Press.

[59] Wilson, M. (2003). Discovery listening-improving perceptual processing. ELT Journal, 57, 335-343.

Behzad Barekat, born in Iran, 1955. Ph.D. in Applied Linguistics, and also Comparative Literature from Sorbonne III, Paris, France, in 2000/2003. Educational interests: Linguistics, Literature, and Translation.

$\mathrm{He}$ is Associate Professor and Head of the English Department at University of Guilan, Rasht, Iran; he has been a University Professor since 1993; he has written 38 articles both in English and Farsi, translated 24 books, published 5 books, performed 6 research projects, and supervised and advised more than 80 M.A. and Ph.D. Theses.

Professor B. Barekat is a Member of Research Committee in Eastern Institute in Sorbonne, Member of International Association of Translators, Member of Editorial Board of 3 Scientific Journals.

Hamed Nobakhti, born in Iran, 1987. M.A. student of TEFL at University of Guilan, Rasht, Iran, in 2012/2014. Educational interests: Linguistics, and Literature. 